\title{
Influence of agronomic practices and pre-harvest conditions on the attachment and development of Listeria monocytogenes in vegetables
}

\author{
Alessandro Miceli ${ }^{1} \cdot$ Luca Settanni $^{1}$ (D) \\ Received: 8 October 2018 / Accepted: 3 January 2019 / Published online: 10 January 2019 \\ (C) Università degli studi di Milano 2019
}

\begin{abstract}
Interest in fresh vegetables is on the increase due to their protective effects against several diseases. Listeria monocytogenes is a human pathogen easily found in vegetables. The purpose of this review article is to analyse the influence of the agricultural practices applied in pre-harvest, the environmental biotic and abiotic factors characterising the cultivation field, as well as the handling procedures at harvest that might greatly influence the presence and the levels of L. monocytogenes in fresh produce. This review article describes the routes of L. monocytogenes infections in relation to the agricultural practices commonly applied during vegetable cultivation. It also analyses the influence of the different cultivation systems as well as the main environmental factors and compares the effects of manual and mechanical harvest retrieving data from literature. Even though post-harvest sanitising is a common practice, fresh produce is still responsible for foodborne diseases. In the last years, the number of cases of human listeriosis is on the increase, and the consumption of fresh vegetables is being more frequently associated with these events. While still relatively rare, human listeriosis is one of the most serious food-borne diseases and continues to be one of the more lethal foodborne pathogens associated with vegetables. Seed decontamination represents an efficient operation to reduce microbial plant internalisation and diffusion. Since L. monocytogenes persists in soil for long periods, the hydroponic systems have been found to reduce its contamination of vegetables.
\end{abstract}

Keywords Agricultural practices $\cdot$ Contamination routes $\cdot$ Food safety $\cdot$ Fresh produce $\cdot$ Listeria monocytogenes $\cdot$ Vegetables

\section{Introduction}

Fruits and vegetables are important components of a healthy diet (FAO 2004). Fresh produce provide a variety of nutrients (vitamins, carbohydrates, and proteins) and numerous healthrelated benefits to the human body due to the phytochemicals with healthy properties (Tango et al. 2018). Thus, increasing the consumption of vegetables is a policy common to several countries. Indeed, the request of vegetables is on the increase with the direct consequence that, over the past 25 years, the world value of trade in vegetables exceeded that of cereals (Chakraborty and Chattopadhyay 2018). This phenomenon is due to the growing awareness of consumers towards the ravages of unhealthy foods (Lynch et al. 2009; Settanni et al.

Luca Settanni

luca.settanni@unipa.it

1 Dipartimento Scienze Agrarie, Alimentari e Forestali, Università degli Studi di Palermo, Viale delle Scienze 4, 90128 Palermo, Italy
2013; Tomasi et al. 2015; Khan et al. 2017) and the direct role of vegetables in reducing the risk of cancers of the organs as well as gastrointestinal tract (Soerjomataram et al. 2010), cardiovascular, coronary heart, metabolic, and degenerative diseases (Karam et al. 2016). It acts as protective foods (Chakraborty and Chattopadhyay 2018).

Nowadays, consumers have a great choice of vegetables that are available in several forms: fresh unprocessed, minimally processed, canned, frozen, cooked, or precooked. Different plant tissues can be consumed fresh or subjected to transformation. The edible parts of the most common vegetables available in retail markets (Table 1) are characterised by substantial differences regarding the structure, nutritional characteristics, mode of consumption, and hygienic characteristics/risks and shelf life. Due to the modern frenetic lifestyle, the demand for healthy foods characterised by high convenience of use has determined the success of fresh-cut vegetables (Miceli and Miceli 2014). In general, vegetables eaten raw are gaining more and more popularity (Ssemanda et al. 2018). Ready-to-eat (RTE) production represents the 
Table 1 Classification of vegetables based on the edible tissues

\begin{tabular}{ll}
\hline Edible tissues & Vegetables \\
\hline Root & Carrot, turnip, radish \\
Tuber & Potato, tapioca \\
Bulb & Onion, garlic, leek \\
Leaf & Cabbage, spinach, chard, lettuce, red chicory, etc. \\
Bud & Soy, asparagus \\
Flower & Cauliflower, broccoli, artichoke \\
Fruit & Tomato, pepper, aubergine, courgette, cucumber, melons, squash, etc. \\
Seed & Pea, bean, fava bean \\
\hline
\end{tabular}

sector of vegetable typology that is increasing more rapidly (Putnik et al. 2011). The consumption of RTE vegetables has also increased in developing countries (Mir et al. 2018).

Among the different typologies of processed vegetables, those treated minimally are characterised by the highest retention of the bioactive components of fresh vegetables, particularly vitamins and phytochemicals, such as polyphenols, flavonoids, sterols, carotenoids, chlorophylls, and anthocyanins, which possess antioxidant properties (Andersen and Jordheim 2006; Siriamornpun et al. 2012). RTE vegetables can be purchased in several forms: "snacks," portioned vegetables to be consumed on the go, "party trays," several portioned vegetables to be consumed at the table, "meals," or lunch boxes. Furthermore, several food distribution chains in France and the UK include "salad bars," shelves with several portioned vegetables for self-service.

A very short shelf life characterises fresh-cut vegetables due to their high perishability caused by the high moisture content (Orsat et al. 2006) and, especially, because the wounding associated with processing leads to several physical and physiological changes that affect their quality (Saltveit 1997; Miceli et al. 2013, 2014, 2015a, b). Thus, the alteration of produce quality due to minimal processes cannot be avoided (Ansah et al. 2018) because the microorganisms enter through wounded tissues (Hussein et al. 2018), such as a tear in the waxy plant cuticle (Shenoy et al. 2017). The rate of microbial growth in fresh-cut vegetables increases with the reduction of leaf size due to cutting (Francis et al. 2012). As a matter of fact, fresh-cut vegetables deteriorate faster than intact produce. Furthermore, disrupted cells release their content (excellent source of energy and nutrients to support microbial proliferation) with the direct consequence that several microorganisms can easily grow (Alfonzo et al. 2018; Miceli et al., 2019). However, due to the different nutritional availabilities caused by the cutting operation, microbial alterations of fresh entire vegetables can differ from those of fresh-cut produce (Barth et al. 2009).

All steps along the crop cultivation cycle for the production of raw produce are indicated as "pre-harvest" (Wos 2016), and the microbial contamination of fresh vegetables occurs mainly at this stage. This contamination is due to the direct contact with faeces and soil particles, to air, dust, insects, and the water used for irrigation, fertigation, or for reconstituting fungicides and insecticides, to inadequately composted manure as well as to animal and human handling (Beuchat 1996; Buck et al. 2003; Islam et al. 2004; Olaimat and Holley 2012; Rajwar et al. 2016). The pre-harvest microbial contamination plays a defining role on the microbiological quality of unprocessed and minimally processed vegetables. Even though post-harvest cleaning is applied to vegetables, the sanitisation is a difficult process because the complete elimination of pathogens cannot be pursued by the conventional methods of sanitation applied on plant surfaces (Olaimat and Holley 2012). Currently, the only way growers can reduce the possibility of contaminating their produce with foodborne pathogens is to utilise preventative measures on-farm (Kader 2006). The microbiological quality of vegetables is also affected by harvest, during transport, and through the application of process operations and storage (Martínez-Sánchez et al. 2006).

Although spoilage bacteria, yeasts, and moulds dominate the microflora of fruits and vegetables, pathogenic bacteria, parasites, and viruses capable of causing human infections are occasionally present on these produce (Beuchat 2002; Cheong et al. 2009). The presence of pathogenic bacteria on fresh-cut products that are consumed raw can cause food-borne outbreaks (Stuart et al. 2006; Settanni et al. 2012; Buchanan et al. 2017). This review focuses on the main factors at the pre-harvest and harvest stages (Fig. 1) affecting the hygienic quality of vegetables, in terms of the presence of Listeria monocytogenes, and analyses the risks related to their consumption.

\section{Food-borne pathogens vectored by fresh vegetables}

The increasing demand for fresh vegetables generated a big challenge: to produce high volumes of vegetables with high (organoleptic and nutritional) quality characterised by highly hygienic standards. The bacterial pathogens frequently found associated with vegetables are Aeromonas hydrophila, Bacillus cereus, Clostridium spp., Escherichia coli 


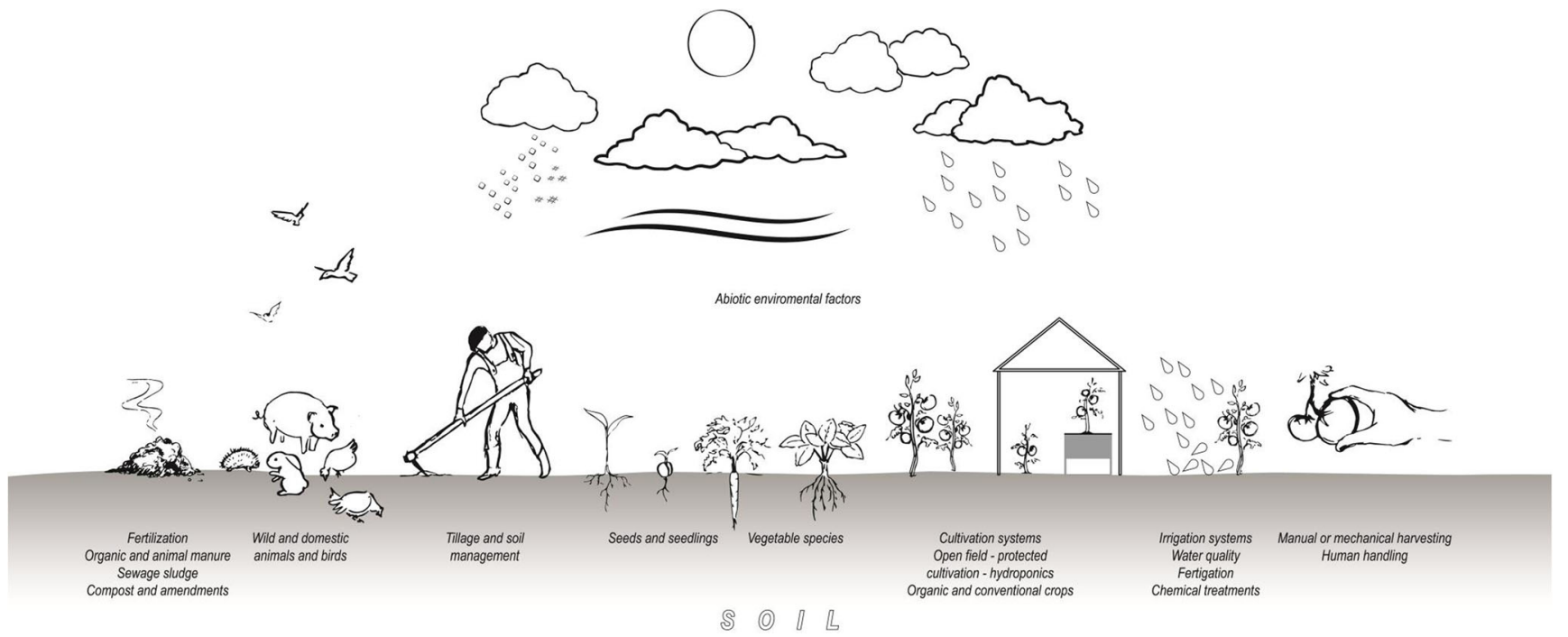

Fig. 1 Factors influencing the presence of L. monocytogenes in vegetables

O157:H7, L. monocytogenes, Salmonella spp., Shigella spp., Vibrio cholerae, Campylobacter spp., and Yersinia enterocolitica (Beuchat 2002) with L. monocytogenes, Salmonella enterica, B. cereus, and E. coli being the most common species (Little et al. 2007; Valero et al. 2007; Cordano and Jacquet 2009; Taban and Halkman 2011; Faour-Klingbeil et al. 2016; Tango et al. 2018). Regarding the last pathogen, in 2011, the contamination of different vegetable products by the serovar O124 caused the death of several persons of different ages in Northern Europe (Moulson 2011), and this event generated a big alert in the entire continent.

Several bacterial mechanisms contribute to the attachment (Gorski et al. 2004) of human enteric pathogens to vegetables, such as the presence or absence of fimbriae (Fratamico et al. 1996), extracellular polymeric substances (Junkins and Doyle 1992) and biofilm formation (Whipps et al. 2008; Zhu et al. 2017), cell surface hydrophobicity (Dickson and Koohmaraie 1989), divalent cationic bridges (Hassan and Frank 2003), and bacterial surface charge (Tromp et al. 2010). Furthermore, internalisation of pathogens in plants plays a crucial role (Whipps et al. 2008; Macarisin et al. 2017). For this purpose, it is considered that bacterial flagellum is a critical factor (Gorski et al. 2003). However, in case of L. monocytogenes, not all strains need this cell appendix for plant colonisation, but the fitness of colonisation is improved by flagellumfunctional motility (Gorski et al. 2009). Olaimat and Holley (2012) suggested to deeply investigate the route followed by pathogens into the vascular system to reduce the risk of foodborne pathogen development.

L. monocytogenes is often found in leafy vegetables (Aparecida et al. 2010; Zhu et al. 2017). In general, it is found with a prevalence around $1 \%$ in fresh-cut products (Tango et al. 2018) right up to almost $4 \%$ in farmers' market fresh produce (Rodriguez-Romo and Yousef 2006). When RTE salads are mixed with other ingredients (such as ham, chicken, salmon, or pasta), the contamination by L. monocytogenes may reach $10 \%$ of products (Söderqvist 2017). Although until 20 years ago L. monocytogenes was among the emerging pathogens (Farber 2000), nowadays, it is recognised as a danger to humans due to the high fatality rate exceeding $30 \%$ (Drevets and Bronze 2008).

\section{Incidence of listeriosis caused by fresh vegetables}

The genus Listeria includes 18 species (Orsi and Wiedmann 2016), with Listeria grayi, Listeria innocua, Listeria ivanovii, L. monocytogenes, Listeria seeligeri, and Listeria welshimeri being those mostly characterised (Rocourt and Cossart 1997) and Listeria costaricensis being the species more recently described (Núñez-Montero et al. 2018). Among these species, only L. monocytogenes is recognised as a human and animal pathogen, capable of causing severe infections (Settanni and Corsetti 2007). In particular, it can attack the central nervous system causing listeriosis determining meningoencephalitis and brain abscesses (Join-Lambert et al. 2005). Listeriosis is a disease of immunocompromised individuals, newborns, pregnant women, and the elderly (Schuchat et al. 1991; Vazquez-Boland et al. 2001). The common symptoms of listeriosis are fever, muscle pain, and serious gastrointestinal problems, but infection could also hit the nerve system (headache, confusion, loss of balance) (Kljujev et al. 2018).

L. monocytogenes is ubiquitous in the environment; it is generally found in soil and can be associated with vegetation in decay (Beuchat 1996). Contrary to other pathogens typically associated with the enteric tract of animals, such as Campylobacter, Salmonella, and E. coli, it survives in soil for long periods (Olaimat and Holley 2012); Nicholson et al. 
(2005) registered a L. monocytogenes survival in soil in the range of 45-100 days. Actually, this species prefers high moisture-containing soils (McLaughlin et al. 2011; Falardeau et al. 2018), but physical and chemical properties of soil influence its survival (Locatelli et al. 2013). Falardeau et al. (2018) reported that $L$. monocytogenes survival in soil was correlated with a neutral $\mathrm{pH}$. L. monocytogenes is a very good endophytic coloniser of vegetable plant roots (Kljujev et al. 2018). For these reasons, L. monocytogenes is generally found associated with root crops (Lianou and Sofos 2007). However, until a few years ago, experts of food hygiene and food microbiologists were not acknowledging that L. monocytogenes could represent a problem for the microbial safety of vegetables.

Indeed, L. monocytogenes can contaminate several vegetables (Beuchat 2002), even at low (refrigeration) temperatures (Schuchat et al. 1991); it is known that L. monocytogenes grows at temperatures above $3.8{ }^{\circ} \mathrm{C}$ (Rodriguez-Romo and Yousef 2006). However, this character is dependent on the interaction between $\mathrm{pH}$ and temperature (De Roever 1998). In general, L. monocytogenes can grow in the range of $\mathrm{pH}$ 4.3-9.4 (Te Giffel and Zwietering 1999). Storage temperatures at retail and domestic level, duration of storage, and portion sizes are the factors that mostly affect the risk of listeriosis due to the consumption of vegetables (Tromp et al. 2010; Ding et al. 2013; Sant'Ana et al. 2014).

The ingestion of contaminated milk and meat-derived products and vegetables is considered to be the primary source of infection for both sporadic and epidemic human listeriosis (Schlech et al. 1983). Also, L. innocua frequently occurs in food and it can be considered as a bacterium indicator for the presence of $L$. monocytogenes; for this reason, L. innocua is often used as a surrogate species of $L$. monocytogenes for experimental trials carried out in safety conditions (Oliveira et al. 2010). Both species have been isolated from soil and vegetables, indicating that the pathogen is almost ubiquitous in nature (Schuchat et al. 1991). A recent work carried out on 602 samples of pre-cut and uncut vegetables purchased in retail markets in Italy showed an overall prevalence of $1 \%$ Listeria spp. represented by L. innocua and L. seeligeri (Santarelli et al. 2018).

The number of human listeriosis confirmed cases increased in the last years with 2536, 2242, and 1720 cases registered in the European economic area in 2016, 2014, and 2012, respectively, even though Listeria is rarely above the food safety limits set by the EU for RTE foods (EFSA 2017). The EU countries with the highest number of listeriosis notified in 2016 were Germany, France, Spain, the UK, and Italy. However, this disease has a low incidence in Europe, since only 1437 listeriosis infections were directly acquired in EU countries out of the total of 2536 cases registered in the EU in 2016. As matter of fact, listeriosis is characterised by a consistent social and public health impact as being the foodborne disease with the highest hospitalisation and mortality rate (99.1 and 15.6\%, respectively) (Scientific Report of EFSA and ECDC 2015). At the EU level, the proportion of listeriosis cases among elderly people has steadily increased from $52.9 \%$ in 2008 to $61.9 \%$ in 2016 . The case fatality was 18.9 and $26.1 \%$ in the age group over 64 and 84 years, respectively, in 2016 (EFSA 2017).

In 2016, 13 EU member states provided data from investigations of L. monocytogenes on 1772 units of RTE fruits and vegetables tested using the detection method, and half of these data were reported by Italy. L. monocytogenes was detected in $2.0 \%$ of the tested samples of RTE salads in Europe (EFSA 2017), showing a consistent presence of this pathogen, despite the control measures being applied (Gil et al. 2015). Table 2 reports the outbreaks caused by the presence of L. monocytogenes in fresh produce from 2010 until present.

\section{Environmental factors}

The conditions at the growing location are major components that influence the microbial safety of raw products (Brackett 1999). The geographical and climatic conditions in which vegetables are cultivated and harvested may have a wide range of variations (Gil et al. 2015). However, different environmental (abiotic and biotic) factors, especially climate conditions, may contribute to L. monocytogenes proliferation on fresh produce. For these reasons, among the farm management practices considered for limiting pre-harvest pathogen contamination, also meteorological factors should be considered (Pang et al. 2017).

Indeed, the interactions between environmental conditions and the native microbiota of vegetables are particularly

Table 2 Food-borne outbreaks caused by L. monocytogenes in fresh vegetables from 2010 to present

\begin{tabular}{|c|c|c|c|c|c|}
\hline Product & Cases & Deaths & Year & Country & Reference \\
\hline RTE celery & 10 & 5 & 2010 & USA & $\begin{array}{l}\text { (Gaul et al. } \\
\text { 2013) }\end{array}$ \\
\hline Cantaloupe & 146 & 33 & 2011 & USA & (CDC 2016) \\
\hline Romaine lettuce & 99 & 15 & 2011 & USA & $\begin{array}{l}\text { (Shrivastava } \\
\text { 2011) }\end{array}$ \\
\hline Vegetables & 3 & 1 & 2013 & Germany & $\begin{array}{l}\text { (Ricci et al } \\
\text { 2018) }\end{array}$ \\
\hline $\begin{array}{l}\text { Mung bean } \\
\text { sprouts }\end{array}$ & 5 & 2 & 2014 & USA & $\begin{array}{c}\text { (Garner \& } \\
\text { Kathariou } \\
\text { 2016) }\end{array}$ \\
\hline RTE salad & 32 & 4 & 2014 & Switzerland & $\begin{array}{l}\text { (CDC 2016b, } \\
\text { Stephan et al } \\
\text { 2015) }\end{array}$ \\
\hline Packaged salad & 19 & 1 & 2016 & USA & (CDC 2016b) \\
\hline Frozen vegetables & 9 & 3 & 2016 & USA & (CDC 2016a) \\
\hline Frozen vegetables & 0 & 0 & 2018 & Italy & This work \\
\hline
\end{tabular}


complex (Devleesschauwer et al. 2017). Pang et al. (2017) found that the amount and frequency of rain precipitation and the speed of the wind can affect the presence of L. monocytogenes in farms with mixed production. This evidence suggests that run-off and soil particles or dust driven by the wind might be responsible for the diffusion of this pathogen. Rain events are associated with an increased prevalence of foodborne pathogens in production environments. Weller et al. (2015) found that the likelihood of Listeria species and L. monocytogenes isolation from spinach field soils was highest during the $24 \mathrm{~h}$ immediately following rain and irrigation events. That study showed the possibility of limiting the contamination of fresh vegetables with $L$. monocytogenes by simply avoiding irrigation before harvest. Among biotic factors, wild and domestic animals, including mammals, birds, reptiles, and insects are direct sources of pathogenic bacteria in agricultural environments (De Roever 1998), because their faeces might contain several pathogens of intestinal origin (Ackers et al. 1998). Birds can be a particularly important contamination source because of their ability to transmit bacteria over long distances. For example, it has been reported that gulls feeding at sewage works are an important vector for subsequently introducing $L$. monocytogenes and enteric bacteria into the agricultural environment (Fenlon 1985).

\section{Seed germination and seedlings}

Among the effects of farm management practices on the microbial contamination of vegetables, planting procedures are reported to be responsible for the transfer of $L$. monocytogenes (Park et al. 2012). Human pathogen bacteria, including L. monocytogenes, could exist on the edges of damaged seeds during germination, and this determines their entrance into the plants (Gorski et al. 2004). However, this aptitude is considered a strain-dependent character (Gorski et al. 2009). Minute tears in the root tissue during germination facilitate this process (Erickson et al. 2014). Jablasone et al. (2005) found that L. monocytogenes became established and persisted in 9-dayold seedlings obtained from inoculated seeds of cress, radish, spinach, lettuce, mustard, carrots, and tomatoes. In that condition, $L$. monocytogenes was not found inside seedling tissues but persisted on plant surface during all the cultivation period. Similarly, Milillo et al. (2008) found that if Arabidopsis thaliana (a well characterised plant model) seeds were exposed to L. monocytogenes, between 4.23 and $4.57 \log \mathrm{CFU} / \mathrm{cm}^{2}$ were recovered from the leaves 7 days post-germination, suggesting that contaminated seeds can produce contaminated plants. This might represent a relevant issue if contamination occurs during vegetable seedling production in nurseries, from which contaminated plants can be transferred to large cultivation areas.
Based on the previous results, Settanni et al. (2012) also focused the attention on the transfer of $L$. monocytogenes from contaminated soil to aromatic plants sown on contaminated soil. To this end, basil and rocket were followed because they represent different growth habitus, rosette, or caulescent plants, respectively. The soils inoculated with L. monocytogenes were monitored for its presence during the cultivation and showed a reduction of the initial inoculums. At harvest, both plant and soil were analysed by culture-independent analysis that confirmed the contamination of the soil but did not find L. monocytogenes on plant leaves. Similar results were reported for sweet pepper by Füstös et al. (2017). The authors performed pepper seed bacterization using L. monocytogenes and E. coli, but the culturedependent and -independent techniques applied on 6-7-weekold plants did not evidence the presence of stable or transient colonies of the inoculated bacteria, concluding that human bacterial pathogens are not able to internalise germinating seeds of sweet pepper.

Seeds are also considered the main source of contamination for sprouts. It is very difficult to wash off or inactivate pathogens from sprout (Saroj et al. 2006). The biofilms that can be formed on cotyledons, hypocotyls, and roots are structures that protect $L$. monocytogenes, making it resistant to antimicrobial compounds (Fett 2000; Lisa et al. 2004). Thus, due to the difficulty in guaranteeing pathogen-free raw sprouts, in 1999 the U.S. government issued a warning regarding the hazard of eating raw sprouts (NACMCF 1999).

Although L. monocytogenes can also internalise vegetables during post-harvest washing (dump tank washing and immersion-type hydrocooling) as registered by Macarisin et al. (2014) with cantaloupes, seed decontamination is an efficient operation to reduce microbial plant internalisation. For this purpose, a promising strategy to decontaminate seeds during storage and at germination is represented by plasma technology, which is also reported to enhance seed germination and growth of plants and beneficial microorganisms (Ito et al. 2018).

\section{Cultivation system}

The farm is a dynamic environment where pathogens and agricultural practices/human interventions, as well as environmental factors and animal/insects, interact continuously (Kumar and Thakur 2018). Vegetables are cultivated using various agricultural inputs and technologies and on farms or in protected culture of varying sizes (Gil et al. 2015).

From the microbiological perspective, protected cultivation is assumed to be safer than open field; this is related to the limitation of some risk factors linked with sources of preharvest contamination (Orozco et al. 2008a, b). Greenhouse cultivation is often associated with hydroponics. Hydroponic cultivation systems are largely adopted for vegetables. These methods allow the growing of plants out of the soil (with or 
without a solid substrate) using nutrient solutions made with water fortified with essential nutrients. Plant roots may be directly dipped in the nutrient solution or plants may grow on mineral (perlite, rockwool, etc.) or organic (coconut fibre, peat, etc.) medium. Nutrient solution may be the vector of microorganism and spread contaminations among plants. Nevertheless, even if some studies detected colonies of Salmonella spp. and pathogenic $E$. coli in this type of crop management system (Orozco et al. 2008a, b), L. monocytogenes was not detected in hydroponically grown tomato (López-Gálvez et al. 2014) and bell peppers and the materials associated with their production (Avila-Vega et al. 2014). On the contrary, Koseki et al. (2011) observed that spinach leaves grown in a hydroponic cultivation system can be contaminated by L. monocytogenes through the root system if the nutrient solution was added with a cell density of $10^{6} \mathrm{CFU} / \mathrm{ml}$. To better investigate pathogen plant internalisation, Settanni et al. (2013) tested several species, including L. monocytogenes, in hydroponic systems that facilitate the contact of bacteria and plant roots using radish as vegetable plant model. The food pathogenic bacteria were inoculated in the nutrient solution during the growth period. At harvest, only Citrobacter freundii, Enterobacter spp., and Klebsiella oxytoca internalised, while L. monocytogenes and the other bacteria tested were not found in radishes. On the contrary, Shenoy et al. (2017) found viable cells of L. monocytogenes in pith, cortex, xylem, phloem, and epidermis of lettuce plants cultivated under greenhouse conditions. Considering that the extent of internalisation also depends on the type and age of the plant (Alegbeleye et al. 2018), these studies suggest that the contamination could be related to vegetable species.

Organic and conventional agriculture differ greatly in the amounts of organic matter inputs during cultivation, which may determine the increase of contamination risks. Oliveira et al. (2010) evaluated the microbiological quality of fresh lettuce from organic and conventional productions, monitoring 18 farms, but none of the sampled objects of study hosted L. monocytogenes. The absence of this microorganism in lettuce was attributed not only to its absence in soil and water but also to the background microbiota present on the vegetables that might exert an inhibitory effect on L. monocytogenes.

Kuan et al. (2017) stated that one particular type of farming practices would not affect the microbiological profiles of fresh produce, because no trend was shown that either organically or conventionally grown cabbage, carrot, calamondin, cherry tomato, Bird's eye chilli, cucumber, eggplant, winged bean, lettuce, sweet potato, tomato, and white radish posed significant microbiological risks. Thus, those authors argued that to guarantee safe fresh produce with a good hygienic quality, appropriate post-harvest handling practices should be followed for any kind of vegetable, regardless of farming methods.

Kljujev et al. (2018) compared the presence of Listeria spp. and L. monocytogenes in different vegetables (tomato, sweet peppers, cabbage, hot pepper, cucumber, potato, carrot, and parsley) grown under field and greenhouse conditions showing that $25.58 \%$ of samples were infected by Listeria spp., but only one carrot sample cultivated in open field was positive for L. monocytogenes.

Tillage or cover crops can modify soil microbial biomass and composition, but no apparent effect of tillage or cover crop on the presence of Listeria on fruits of muskmelon produced with different soil management and tillage was registered (Krzton-Presson et al. 2016). Nevertheless, there is evidence that L. innocua can overwinter and persist for more than 10 months in the soil; thus human pathogens cannot be eliminated by leaving a field fallow over the winter (KrztonPresson et al. 2016).

Mulching is one of the techniques used for the cultivation of vegetables that stands out for improving crop productivity and quality. Plastic mulching, especially, increases soil moisture and temperature, thus changing the biological characteristics, enhancing soil microbial biomass, cycling nutrients, and providing a more stable soil microenvironment (Li et al. 2004). Differences in cultivation methods (plastic mulch vs bare soil) may affect the microflora counts at harvest and its behaviour during postharvest storage of products. Mulching can give cleaner products as it separates the soil from plants, but it has been registered that it determines a higher microbial count than plants from bare soil at harvest (Agüero et al. 2008; Ponce et al. 2008). These conditions could be favourable also for foodborne pathogens, although, so far, there is no direct evidence of the effect of plastic mulching on L. monocytogenes.

\section{Influence of irrigation water and irrigation system}

The demand for water for agriculture purposes has increased as a consequence of changes in the precipitation patterns and increase in the world's population (Forslund et al. 2010). The increasingly limited water supplies call for alternative solutions, and the European Water Framework Directive (2000/60/EC) encourages and promotes the use of treated urban wastewater in agriculture. This agronomic practice is becoming common; it occurs in many Countries (Scott et al. 2004) because it is of high value for the horticultural crops. However, when irrigation is performed with wastewater, the presence of microbial pathogens (Hamilton et al. 2005; Toze 2006) has to be considered.

A recent review article published by Jongman and Korsten (2018) discussed the global water challenges associated with irrigation water and deeply analysed the microbial quality of source water for irrigation, including groundwater, municipal water, rainwater, surface water, and wastewater and reported the crop contaminations for leafy greens. In particular, the authors highlighted the aspects related to the microbiological quality of roof-harvested rainwater that was not the object of any previous reviews, reporting the presence of Salmonella 
spp., Campylobacter spp., and L. monocytogenes, but concluded that roof-harvested rainwater is an alternative source of water for irrigation of leafy green vegetables. However, all unprotected sources represent a risk for L. monocytogenes transfer. Ssemanda et al. (2018) found a prevalence of $1.0 \%$ L. monocytogenes in farm vegetables in Rwanda where all the water used for irrigation was from marshlands, rivers, lakes, and runoff lagoons.

The microbiological safety of fresh produce is greatly influenced by the irrigation system applied (Brackett 1999; Aruscavage et al. 2006; Warriner et al. 2009). To this end, the irrigation types that mostly represent a risk for leafy vegetables are spray and flood, since the contaminated water makes direct contact with the edible plant portions and also determines the transfer of soil particles (U.S. Food and Drug Administration 1998). Settanni et al. (2012) demonstrated that watering pots containing soil artificially contaminated with L. monocytogenes from below (sub-irrigation) did not determine the contamination of the aerial parts of leafy vegetables. For this reason, the transmission of pathogens by drip irrigation with contaminated water is very low in comparison to the irrigation performed by overhead sprinklers. Water is not only responsible for vegetable contamination in pre-harvest, since during the application of post-harvest operations it might also cause problems related to the development of foodborne pathogens (Berger et al. 2010; Macarisin et al. 2014).

\section{Fertilisation}

To achieve high yields with appropriate fruit and leaf size and good taste, the plant should be provided with good cultivation practices, namely proper fertilisation (Dzida and Pitura 2008). Although the soil is a natural environment for a wide variety of human pathogens, their presence is broadened considerably by the addition of animal wastes (Whipps et al. 2008). Fields that contain animal manure are more likely to be contaminated with enteric pathogens because of their ability to survive in soils for months or years (Doyle and Erickson 2008).

Inadequate composting is responsible for the transmission of undesired microorganisms from manures to the soil (Beuchat and Ryu 1997; De Roever 1998; Natvig et al. 2002; Santamaria and Toranzos 2003). Hutchison et al. (2004) reported that spreading livestock manure on the top of agricultural soil and letting it age without mixing them into the soil significantly reduced counts of pathogenic bacteria such as E. coli O157:H7, S. enterica, L. monocytogenes, and Campylobacter jejuni. L. monocytogenes can persist in a viable state for months when sewage sludge is applied to soil (Watkins and Sleath 1981). However, the survival of pathogens in the soil is time-dependent and, as such, the longer the interval between application of the contaminated vehicle and the harvest of the plant, the greater the likelihood that the product would not be contaminated. Consequently, the level of contamination and the time in the growing cycle at which the contamination event takes place would be important indicators for whether contamination of the plant at harvest is likely (Doyle and Erickson 2008).

As reported above, leafy vegetables are greatly affected by the contact with soil particles for what concerns their microbiological aspects. For this reason, these vegetables have been deeply investigated for the influence of fertilisers on their hygiene quality. From this perspective, lettuce is the species investigated more extensively. The study of Oliveira et al. (2011) aimed to investigate the transfer of L. innocua from soil to lettuce. For this purpose, the researchers applied artificially contaminated compost or performed the irrigation with contaminated water. After sprinkling, the population of L. innocua on lettuce leaves was at high levels, but it was undetectable under field conditions. The transfer of L. innocua was not registered when soil was contaminated through compost. In general, the levels of L. innocua in the soil and on lettuce were highly similar independently of the manner of contamination (via application of contaminated compost or contaminated water). Girardin et al. (2005) investigated the behaviour of L. innocua in parsley cultivated in fields amended with bovine manure or municipal waste sewage sludge. Both sources of organic matter were composted before application, and the irrigation was performed by sprinkling using groundwater. After 90 days, the levels of L. innocua detected in the soil were 7 orders of magnitude lower than those registered at the beginning of the experimentation. During the first 30 days, this indicator was found at very low numbers on the leaves of parsley. The effect of the temperature was clearly evidenced since a high survival of L. innocua was observed during winter. In that study, L. innocua was mostly transferred from soil to leaves through the splash effect due to rain or irrigation, while the internalisation from the soil did not occur. For this reason, a period of 90 days represents a right delay between the fertilisation with contaminated material and harvest to contain the risk of transfer of the pathogenic L. monocytogenes.

Consumers are requesting organic foods more and more. The increasing demand for these foods, especially fresh produces, generated food safety issues related to the cultivation practices. Stuart et al. (2006) also indicated the dangers that farming operations pose to environmental sustainability and considered the ecological aspects of the guidelines for food safety. In this direction, recycled organic wastes are being used as alternative sources for enhancing soil since they increase the organic content of soil and stimulate its biological activity. The application of the organic wastes in place of synthetic fertilisers also improves the physical structure of the soil and allows an increase of the plant yield and resistance to diseases (Bulluck et al. 2002; Bulluck and Ristaino 2002). However, the work of Maurice Bilung et al. (2018) showed the occurrence of Listeria spp., both in organic and conventional vegetable farms, but, so far, 
only limited information on the comparison of conventionally, organically and hydroponically vegetables contaminated by L. monocytogenes are available in the literature (Maffei et al. 2016).

The agricultural practice referred to as "fertigation" is the injection of water-soluble fertilisers into an irrigation system to distribute nutrients fusing irrigation water. This technique is practised extensively in commercial agriculture and horticulture and could be a source of pathogen distribution. López-Gálvez et al. (2014) found that the concentrated stock solutions used for fertigation of a hydroponic system contained high levels of Listeria spp. (around $4.5 \log \mathrm{cfu} / 100 \mathrm{~mL}$ ), especially in the case of the potassium nitrate solution. Selma et al. (2007) reported that fertiliser solutions could be an additional source of Listeria spp., which increases the levels of Listeria spp. initially present in surface water or reclaimed water.

\section{Harvest}

During harvest, the handling of the vegetables can greatly contribute to the microbiological contamination (Beuchat 2002). Furthermore, Park et al. (2013) stated that the personal hygiene of field workers' represents an additional factor that influences the pre-harvest microbial contamination of fresh produce. The increasing global demand for vegetables has determined the diffusion of mechanised horticulture (Siddiqui et al. 2011). Hence, large-scale planting and mechanical handling during harvest are necessary (Hussein et al. 2018).

Root crops (carrots and potatoes) but also some leafy vegetables are mainly produced on a large-scale in European countries with harvesting machine and automatic grading, giving little possibility for direct contact between workers' hands and harvested products (Monaghan 2014). However, small-scale growers perform manual harvesting and grading of vegetables, with the consequent prolonged and intense contact between vegetables and workers' hands (Monaghan and Hutchison 2016). The hands of workers in the food sector contaminated by human pathogens can be implicated in foodborne outbreaks (Todd et al. 2010). Contaminated workers' hands were implicated in the transfer of S. enterica serotype Enteritidis on lettuce (Waitt et al. 2014) and E. coli O157:H7 on strawberries (Shaw et al. 2015). Hand contamination was also the cause of transferred contamination of generic E. coli to carrots (Monaghan and Hutchison 2016). A similar contamination route could be supposed for L. monocytogenes.

The majority of investigations have been focused on food handlers in the post-harvest chain until restaurants or other high-throughput food preparation areas, but the implementation of correct hand hygiene is of relevance also for farm workers. The application of hand sanitisers and the use of portable latrines, as well as adequate training of the workers in their use brought about a reduction of spinach contamination by generic E. coli (Park et al. 2013).

\section{Biological control of $L$. monocytogenes}

Bio-based agents might represent a useful and sustainable tool in the prevention of attachment of L. monocytogenes in vegetables. From this perspective, a successful strategy could be designed on the application of bacteriocins, ribosomally synthesised, extracellularly released lowmolecular-mass peptides or proteins, which have a bactericidal or bacteriostatic effect on other (usually closed related) species (Jack et al. 1995). Among soil bacteria able to compete in situ with L. monocytogens by bacteriocin production, Bacillus genus members are particularly indicated. The species B. cereus, Bacillus coagulans, Bacillus megaterium, Bacillus subtilis, Bacillus thermoleovorans, and Bacillus thuringensis are producers of cerein (Bizani et al. 2005), coagulin (Hyronimus et al. 1998), megacin (von Tersch and Carlton 1983), subtilin (Jansen and Hirschmann 1944) and subtilosin (Zheng and Slavik 1999), and thuricin (Cherif et al. 2001), respectively. Among these bacteria, $B$. thuringiensis is the most promising species to reach the scope of controlling L. monocytogenes in the soil, since it is widely and commonly used in agriculture, mainly for the biological control of pathogenic insects due to the production of $\delta$-endotoxins (Beegle and Yamamoto 1992).

Soil bacteriocin-producing Bacillus isolates with antiListeria activity have been proposed as alternative antibacterial agents for use in the food industry (Aunpad et al. 2011), but so far, no soil applications have been evaluated. Generally, bacteriocins are used as food biopreservatives (Settanni and Corsetti 2008), since they confer a rudimentary form of innate immunity on foodstuffs (Cotter et al. 2005) and they are, generally, produced by lactic acid bacteria (LAB) (Field et al. 2018). However, some class II bacteriocins active against $L$. monocytogenes (Larsen et al. 1993) with potential food applications have been characterised from soil LAB isolates, such as durancin produced by Enterococcus durans (Yanagida et al. 2005) and bacteriocin LB44 by Pediococcus pentosaceus (Kaur and Tiwari 2018). In general, bacteriocin-producing LAB might be associated with the soil (Yanagida et al. 2006). Hence, bacteriocin production plays an important role in bacterial competition strategies in the soil, and this phenomenon should be better investigated and exploited to adopt biological measures to control L. monocytogenes in open fields during vegetable cultivation.

\section{Upcoming technologies: an opportunity to prevent L. monocytogenes attack?}

To keep agriculture on the cutting edge, many farmers now implement a variety of technologies, including precision agriculture, remote sensing, computers, the Internet, specialised softwares, global positioning, drip irrigation, and 
biotechnology (International Food Information Council Foundation 2018). Since information and communication technologies have become a global tool to plan activities in modern agriculture at different levels (Zahedi and Zahedi 2012), traceability technologies, which are already available for farms (Bai et al. 2017), should be developed and targeted to monitor bacteria and follow their route of contamination to implement traceability systems. In view of their application in the prevention of $L$. monocytogenes attack on agro-based products, upcoming technologies show great potential to set the cultivation systems to hamper the growth of this ubiquitous foodborne pathogen.

\section{Concluding remarks and future perspectives}

While still relatively rare, human listeriosis is one of the most serious food-borne diseases under EU surveillance, causing hospitalisation, high morbidity, and high mortality, particularly among the elderly and immunocompromised people as well as pregnant women and infants. In recent years, an increased incidence of foodborne illnesses has been caused by agents vectored by fresh vegetables. Thus, L. monocytogenes continues to be one of the more lethal foodborne pathogens associated with vegetables.

Table 3 Influence of agronomic practices and pre-harvest conditions on the attachment and development of Listeria monocytogenes in vegetables

Agronomic practices and pre- $\quad$ Impact on L. monocytogenes contamination

harvest conditions

Agronomic practices

Seed germination and seedlings

Cultivation system

Irrigation water and irrigation system

Mulching

Fertilisation

Harvest

Environmental factors

Rain

Wind

Wild and domestic animals

Birds
Planting procedures can be responsible for the transfer of $L$. monocytogenes.

The contamination of seedling may occur during their production in nurseries, from which contaminated plants can be transferred to large cultivation areas.

Seeds are also considered the main source of contamination for sprouts.

Protected cultivation is assumed to be safer than open field due to the limitation of some risk factors linked with sources of pre-harvest contamination.

The nutrient solution used in hydroponic cultivation systems may be the vector of microorganism and spread contaminations among plants but the contamination could be related to vegetable species.

Tillage or cover crops can modify soil microbial biomass and composition but no apparent effect of tillage or cover crop on the presence of Listeria was registered. L. innocua is able to overwinter and persist for more than 10 months in the soil, thus human pathogens cannot be eliminated by leaving a field fallow over the winter.

All unprotected water sources represent a risk for L. monocytogenes transfer.

The likelihood of Listeria spp. and L. monocytogenes isolation from field soils is highest during the $24 \mathrm{~h}$ immediately following irrigation. Possibility to limit the contamination of fresh vegetables with L. monocytogenes simply avoiding irrigation before harvest.

Watering pots containing soil contaminated with L. monocytogenes from below (sub-irrigation) did not determine the contamination of the aerial parts of leafy vegetables. Thus, the transmission of pathogens by drip irrigation with contaminated water is very low in comparison to the irrigation performed by overhead sprinklers.

L. innocua can be transferred from soil to leaves through the splash effect due to irrigation.

There are no direct evidences on the effect of plastic mulching on L. monocytogenes.

Inadequate composting is responsible for the transmission of undesired microorganisms from manures to soil.

Listeria monocytogenes is able to persist in viable state for months when sewage sludge are applied to soil.

The level of contamination and the time in the growing cycle at which the contamination event take place would be important indicators for contamination of the plant at harvest.

A period of 90 days represents a right delay between the fertilisation with contaminated material and harvest to contain the risk of transfer of $L$. monocytogenes.

The concentrated stock solutions used for fertigation may contain high levels of Listeria spp.

During harvest, the handling of the vegetables can greatly contribute to the microbiological contamination. The hands of workers in the food sector contaminated by human pathogens can be implicated in foodborne outbreaks. A similar contamination route could be supposed for L. monocytogenes.

Rain events are associated with an increased prevalence of foodborne pathogens in production environments. The splash effect of rain can transfer Listeria spp. from soil to leaves.

Run-off and soil particles or dust driven by the wind might be responsible for the diffusion of this pathogen.

Their faeces might contain several pathogens of intestinal origin.

They can transmit bacteria over long distances, from contaminated places to the agricultural environment. 
During the pre-harvest phases, pathogen populations, including L. monocytogenes, can establish themselves on growing crops, especially on root and leafy vegetables (Table 3). The presence of $L$. monocytogenes on seeds might facilitate its entrance into plants during germination. Thus, seed decontamination represents an efficient operation to reduce microbial plant internalisation and diffusion. Soil contamination plays a defining role on the hygienic characteristics of the product since L. monocytogenes persists in soil for long periods under a wide range of thermal and humidity conditions. To this end, the hydroponic systems have been found to reduce the microbial contaminations of vegetables, but the contamination of the nutrient solutions has to be taken under microbiological control because their massive contaminations are responsible for $L$. monocytogenes transfer. Analysing the cultivation systems and the abiotic and biotic factors, it seems there is a correlation among the agricultural practices and the environmental conditions with the contamination of the vegetable species. This strongly suggests that the choice of vegetable species should be determined after considering how all these parameters influence the attachment and development of L. monocytogenes. Furthermore, farmers' markets are gaining popularity due to the increased consumer demand for locally grown fresh produce. The application of organic wastes and manure accentuated the safety concerns of vegetables. Actually, the risk of human pathogen internalisation in vegetables is very low at harvest, but its occurrence during the first stages of plant development might determine a prolonged persistence in the rhizosphere. Safety issues may also arise when, at harvest, the hygienic habits of workers are scarce.

The application of pre-harvest food safety procedures can contain and reduce the burden of foodborne pathogens in humans at the post-harvest stages. Indeed, an effective preharvest intervention to control foodborne pathogens is currently lacking; due to the importance of bacteriocin production by soil bacteria in bacterial competition strategies, having in place control measures based on the inhibition of L. monocytogenes through in situ release of bacteriocins during vegetable cultivation seems to be a promising route to be investigated and exploited in open fields. Furthermore, the application of transgenic technology in agriculture based on the production of anti-Listeria molecules by plants could be of great usefulness to prevent the attachment of $L$. monocytogenes. However, the early detection and monitoring of pathogens during the pre-harvest steps is still of relevance for the safety aspects at harvest.

Acknowledgements The authors are grateful to Dr. Giuseppe Di Benedetto for the graphical support provided to prepare Figure 1.

Funding information This work received no funds.

\section{Compliance with ethical standards}

Conflicts of interest The authors declare that they have no conflicts of interest.

Research involving human participants and/or animals Not applicable.

Informed consent All authors gave their informed consent in writing.

Publisher's note Springer Nature remains neutral with regard to jurisdictional claims in published maps and institutional affiliations.

\section{References}

Ackers ML, Mahon BE, Leahy E, Goode B, Damrow T, Hayes PS, Bibb WF, Rice DH, Barrett TJ, Hutwagner L, Griffin PM, Slutsker L (1998) An outbreak of Escherichia coli O157:H7 infections associated with leaf lettuce consumption. J Infect Dis 177:1588-1593

Agüero MV, Ponce AG, Moreira MR, Roura SI (2008) Plastic mulch improves microbial quality and shelf life of cold stored butter lettuce (Lactuca sativa var Lores). Fresh Prod 2:6-13

Alegbeleye OO, Singleton I, Sant'Ana AS (2018) Sources and contamination routes of microbial pathogens to fresh produce during field cultivation: a review. Food Microbiol 73:177-208

Alfonzo A, Gaglio R, Miceli A, Francesca N, Di Gerlando R, Moschetti G, Settanni L (2018) Shelf life evaluation of fresh-cut red chicory subjected to different minimal processes. Food Microbiol 73:298304

Andersen OM, Jordheim M (2006) The anthocyanins. In: Andersen OM, Markham KR (eds) Flavonoids: chemistry, biochemistry and applications. CRC Taylor and Francis, Boca Raton, pp 471-552

Ansah FA, Amodio ML, De Chiara MLV, Colelli G (2018) Effects of equipments and processing conditions on quality of fresh-cut produce. J Agric Eng Res 49:139-150

Aparecida OM, Abeid Ribeiro EG, Morato Bergamini AM, Pereira De Martinis EC (2010) Quantification of Listeria monocytogenes in minimally processed leafy vegetables using a combined method based on enrichment and 16S rRNA real-time PCR. Food Microbiol 27:19-23

Aruscavage D, Lee K, Miller S, LeJeune JT (2006) Interactions affecting the proliferation and control of human pathogens on edible plants. $\mathrm{J}$ Food Sci 71:R89-R99

Aunpad R, Sripotong N, Khamlak K, Inchidjuy S, Rattanasinganchan P, Pipatsatitpong D (2011) Isolation and characterization of bacteriocin with anti-listeria and antiMRSA activity produced by food and soil isolated bacteria. Afr J Microbiol Res 5:5297-5303

Avila-Vega DE, Álvarez-Mayorga B, Arvizu-Medrano SM, Pacheco-Aguilar R, Martínez-Peniche R, Hernández-Iturriaga M (2014) Microbiological profile and incidence of Salmonella and Listeria monocytogenes on hydroponic bell peppers and greenhouse cultivation environment. J Food Prot 77:1904-1910

Bai H, Zhou G, Hu Y, Sun A, Xu X, Liu X, Lu C (2017) Traceability technologies for farm animals and their products in China. Food Control 79:35-43

Barth M, Hankinson TR, Zhuang H, Breidt F (2009) Microbiological spoilage of fruits and vegetables. In: Sperber WH, Doyle MP (eds) Compendium of the microbiological spoilage of foods and beverages, food microbiology and food safety. Springer Science+Business Media, New York, pp 135183

Beegle CC, Yamamoto T (1992) History of Bacillus thuringiensis Berliner research and development. Can Entomol 124:587-616

Berger CN, Sodha SV, Shaw RK, Griffin PM, Pink D, Hand P, Frankel G (2010) Fresh fruit and vegetables as vehicles for 
the transmission of human pathogens. Environ Microbiol 12: 2385-2397

Beuchat LR (1996) Pathogenic microorganisms associated with fresh produce. J Food Prot 59:204-216

Beuchat LR (2002) Ecological factors influencing survival and growth of human pathogens on raw fruits and vegetables. Microbes Infect 4 : 413-423

Beuchat LR, Ryu J (1997) Produce handling and processing practices. Emerg Infect Dis 3:459-465

Bizani D, Motta AS, Morrissy JA, Terra R, Souto AA, Brandelli A (2005) Antibacterial activity of cerein $8 \mathrm{~A}$, a bacteriocin-like peptide produced by Bacillus cereus. Int Microbiol 8:125-131

Brackett RE (1999) Incidence, contributing factors, and control of bacterial pathogens in produce. Postharvest Biol Technol 15:305-311

Buchanan RL, Gorris LGM, Hayman MM, Jackson TC, Whiting RC (2017) A review of Listeria monocytogenes: an update on outbreaks, virulence, dose-response, ecology, and risk assessments. Food Control 75:1-13

Buck JW, Walcott RR, Beuchat LR (2003) Recent trends in microbiological safety of fruits and vegetables. Plant Health Progr 10:1094

Bulluck LR, Ristaino JB (2002) Effect of synthetic and organic soil fertility amendments on southern blight, soil microbial communities, and yield of processing tomatoes. Phytopathology 92: 181-189

Bulluck LR, Brosius M, Evanylo GK, Ristaino JB (2002) Organic and synthetic fertility amendments influence soil microbial, physical and chemical properties on organic and conventional farms. Appl Soil Ecol 19:147-160

CDC (2016) Listeria outbreaks. Available at: https://www.cdc.gov/ listeria/outbreaks/Accessed 28 May 2018a

CDC (2016a) Multistate outbreak of listeriosis linked to frozen vegetables (final update). Available at: http://www.cdc.gov/listeria/outbreaks/ frozen-vegetables-05-16/index.html Accessed 28 May 2018b

CDC (2016b) Multistate outbreak of listeriosis linked to packaged salads produced at Springfield, Ohio dole processing facility (final update). Available at: https://www.cdc.gov/listeria/outbreaks/bagged-salads01-16/index.html Accessed 28 May $2018 \mathrm{c}$

Chakraborty I, Chattopadhyay A (2018) Pre- and post-harvest losses in vegetables. In: Singh B, Singh S, Koley TK (ed) Advances in postharvest technologies of vegetable crops, CRC Press Taylor \& Francis

Cheong S, Lee C, Song SW, Choi WC, Lee CH, Kim SJ (2009) Enteric viruses in raw vegetables and groundwater used for irrigation in South Korea. Appl Environ Microbiol 75:7745-7751

Cherif A, Ouzari H, Daffonchio D, Cherif H, Ben Slama K, Hassen A, Jaoua S, Boudabous A (2001) Thuricin 7: a novel bacteriocin produced by Bacillus thuringiensis BMG1. 7, a new strain isolated from soil. Lett Appl Microbiol 32:243-247

Cordano AM, Jacquet C (2009) Listeria monocytogenes isolated from vegetable salads sold at supermarkets in Santiago, Chile: prevalence and strain characterization. Int J Food Microbiol 132:176-179

Cotter PD, Hill C, Ross RP (2005) Bacteriocins: developing innate immunity for food. Natl Rev 3:777-788

De Roever C (1998) Microbiological safety evaluations and recommendations on fresh produce. Food Control 9:321-347

Devleesschauwer B, Marvasi M, Giurcanu MC, Hochmuth GJ, Speybroeck N, Havelaar AH, Teplitski M (2017) High relative humidity pre-harvest reduces post-harvest proliferation of Salmonella in tomatoes. Food Microbiol 66:55-63

Dickson JS, Koohmaraie M (1989) Cell surface charge characteristics and their relationship to bacterial attachment to meat surfaces. Appl Environ Microbiol 55:832-836

Ding T, Iwahori J, Kasuga F, Wang J, Forghani F, Park MS, Oh DH (2013) Risk assessment for Listeria monocytogenes on lettuce from farm to table in Korea. Food Control 30:190-199
Doyle MP, Erickson MC (2008) Summer meeting 2007— the problems with fresh produce: an overview. J Appl Microbiol 105:317-330

Drevets DA, Bronze MS (2008) Listeria monocytogenes: epidemiology, human disease, and mechanisms of brain invasion. FEMS Immunol Med Microbiol 53:151-165

Dzida K, Pitura K (2008) The influence of varied nitrogen fertilization on yield and chemical composition of swiss chard (Beta vulgaris L. var. cicla L.). Acta Sci Pol- Hortorum Cultus 7:15-24

Erickson MC, Webb CC, Diaz-Perez JC, Davey LE, Payton AS, Flitcroft ID, Phatak SC, Doyle MP (2014) Absence of internalization of Escherichia coli $\mathrm{O} 157: \mathrm{H} 7$ into germinating tissue of field-grown leafy greens. J Food Prot 77:189-196

European Food Safety Authority, and European Centre for Disease Prevention and Control (2017) The European Union summary report on trends and sources of zoonoses, zoonotic agents and foodborne outbreaks in 2016. EFSA J 15:e05077

Falardeau J, Walji K, Haure M, Fong K, Taylor GA, Ma Y, Smukler S, Wang S (2018) Native bacterial communities and Listeria monocytogenes survival in soils collected from the Lower Mainland of British Columbia, Canada. Can J Microbiol 64:695705

Faour-Klingbeil D, Murtada M, Kuri V, Todd EC (2016) Understanding the routes of contamination of ready-to-eat vegetables in the Middle East. Food Control 62:125-133

Farber JM (2000) Present situation in Canada regarding Listeria monocytogenes and ready-to-eat seafood products. Int J Food Microbiol 62:247-251

Fenlon DR (1985) Wild birds and silage as reservoirs of Listeria in the agricultural environment. J Appl Bacteriol 59:537-543

Fett WF (2000) Naturally occurring biofilms on alfalfa and other types of sprouts. J Food Prot 63:625-632

Field D, Ross RP, Hill C (2018) Developing bacteriocins of lactic acid bacteria into next generation biopreservatives. Curr Opin Food Sci 20:1-6

Food and Agriculture Organization of the United Nations/World Health Organization. 2004. Fruit and vegetables for health: report of the Joint FAO/WHO Workshop on Fruit and Vegetables for Health, 1-3 September 2004, Kobe, Japan, Available at: http://appswhoint/iris/handle/10665/43143 Accessed 28 May 2018

Forslund A, Ensink JHJ, Battilani A, Kljujev I, Gola S, Raicevic V, Jovanovic Z, Stikic R, Sandei L, Fletcher T, Dalsgaarda A (2010) Faecal contamination and hygiene aspect associated with the use of treated wastewater and canal water for irrigation of potatoes (Solanum tuberosum). Agric Water Manag 98:440 450

Francis GA, Gallone A, Nychas GJ, Sofos JN, Colelli G, Amodio ML, Spano G (2012) Factors affecting quality and safety of fresh-cut produce. Crit Rev Food Sci Nutr 52:595-610

Fratamico PM, Schultz FJ, Benedict RC, Buchanan RL, Cooke PH (1996) Factors influencing attachment of Escherichia coli O157: $\mathrm{H} 7$ to beef tissues and removal using selected sanitizing rinses. J Food Prot 59:453-459

Füstös Z, Belák Á, Maráz A (2017) Colonization ability of Escherichia coli and Listeria monocytogenes in the endosphere of sweet pepper (Capsicum annuum var. grossum). Acta Aliment 46:481-491

Garner D, Kathariou S (2016) Fresh produce-associated listeriosis outbreaks, sources of concern, teachable moments, and insights. J Food Prot 79:337-344

Gaul LK, Farag NH, Shim T, Kingsley MA, Silk BJ, Hyytia-Trees E (2013) Hospital-acquired listeriosis outbreak caused by contaminated diced celery-Texas, 2010. Clin Infect Dis 56:20-26

Gil MI, Selma MV, Suslow T, Jacxsens L, Uyttendaele M, Allende A (2015) Pre-and postharvest preventive measures and intervention 
strategies to control microbial food safety hazards of fresh leafy vegetables. Crit Rev Food Sci Nutr 55:453-468

Girardin H, Morris CE, Albagnac C, Dreux N, Glaux C, Nguyen-The C (2005) Behaviour of the pathogen surrogates Listeria innocua and Clostridium sporogenes during production of parsley in fields fertilized with contaminated amendments. FEMS Microb Ecol 54:287295

Gorski L, Palumbo JD, Mandrell RE (2003) Attachment of Listeria monocytogenes to radish tissue is dependent upon temperature and flagellar motility. Appl Environ Microbiol 69:258-266

Gorski L, Palumbo JD, Nguyen KD (2004) Strain-specific differences in the attachment of Listeria monocytogenes to alfalfa sprouts. J Food Prot 67:2488-2495

Gorski L, Duhe JM, Flaherty D (2009) The use of flagella and motility for plant colonization and fitness by different strains of the foodborne pathogen Listeria monocytogenes. PLoS One 4:e5142

Hamilton AJ, Boland AM, Stevens D, Kelly J, Radcliffe J, Ziehrl A, Dillon P, Paulin B (2005) Position of the Australian horticultural industry with respect to the use of reclaimed water. Agric Water Manag 71:181-209

Hassan AN, Frank JF (2003) Influence of surfactant hydrophobicity on the detachment of Escherichia coli $\mathrm{O} 157: \mathrm{H} 7$ from lettuce. Int J Food Microbiol 87:145-152

Hussein Z, Fawole OA, Opara UL (2018) Preharvest factors influencing bruise damage of fresh fruits-a review. Sci Hortic 229:45-58

Hutchison ML, Walters LD, Moore A, Crooks KM, Avery SM (2004) Effect of length of time before incorporation on survival of pathogenic bacteria in livestock wastes applied to agricultural soil. Appl Environ Microbiol 70:5111-5118

Hyronimus B, Le Merrec C, Urdaci MC (1998) Coagulin, a bacteriocinlike inhibitory substance produced by Bacillus coagulans I4. J Appl Microbiol 85:42-50

International Food Information Council Foundation (2018) Background on agricultural practices and food technologies. https://www. foodinsight.org/Background_on_Agricultural_Practices_and Food Technologies Accessed 30 Nov 2018

Islam M, Morgan J, Doyle MP, Phatak SC, Millner P, Jiang X (2004) Fate of Salmonella enterica serovar Typhimurium on carrots and radishes grown in fields treated with contaminated manure composts or irrigation water. Appl Environ Microbiol 70:2497-2502

Ito M, Oh JS, Ohta T, Shiratani M, Hori M (2018) Current status and future prospects of agricultural applications using atmosphericpressure plasma technologies. Plasma Process Polym 15:1700073

Jablasone J, Warriner K, Griffiths M (2005) Interactions of Escherichia coli O157: H7, Salmonella typhimurium and Listeria monocytogenes plants cultivated in a gnotobiotic system. Int $\mathrm{J}$ Food Microbiol 99:7-18

Jack RW, Tagg JR, Ray B (1995) Bacteriocins of Gram-positive bacteria. Microbiol Rev 59:171-200

Jansen EF, Hirschmann DJ (1944) Subtilin, an antibacterial substance of Bacillus subtilis: culturing condition and properties. Arch Biochem 4:297-309

Join-Lambert OF, Ezine S, Le Monnier A, Jaubert F, Okabe M, Berche P, Kayal S (2005) Listeria monocytogenes-infected bone marrow myeloid cells promote bacterial invasion of the central nervous system. Cell Microbiol 7:167-180

Jongman M, Korsten L (2018) Irrigation water quality and microbial safety of leafy greens in different vegetable production systems: a review. Food Rev Int 34:308-328

Junkins AD, Doyle MP (1992) Demonstration of exopolysaccharides production by enterohemorrhagic Escherichia coli. Curr Microbiol 25:9-17

Kader AA (2006) Assessment of post-harvest practices for fruits and vegetables in Jordan. United States Agency for International Development. Available at: http://www.ncare.gov.jo/ OurNCAREPages/PROJECTMENU/RelatedPages/KAFAA/
Kafa\%27a\%20assessment/A-20.\%20Assessment\%20of\%20Post $\%$ 20Harvest.pdf Accessed 23 May 2018

Karam MC, Petit J, Zimmer D, Djantou EB, Scher J (2016) Effects of drying and grinding in production of fruit and vegetable powders: a review. J Food Eng 188:32-49

Kaur R, Tiwari SK (2018) Membrane-acting bacteriocin purified from a soil isolate Pediococcus pentosaceus LB44 shows broad host-range. Biochem Biophys Res Commun 498:810-816

Khan I, Tango CN, Miskeen S, Lee BH, Oh D-H (2017) Hurdle technology: a novel approach for enhanced food quality and safety-a review. Food Control 73:1426-1444

Kljujev I, Raicevic V, Jovicic-Petrovic J, Vujovic B, Mirkovic M, Rothballer M (2018) Listeria monocytogenes - danger for health safety vegetable production. Microb Pathog 120:23-31

Koseki S, Mizuno Y, Yamamoto K (2011) Comparison of two possible routes of pathogen contamination of spinach leaves in a hydroponic cultivation system. J Food Prot 74:1536-1542

Krzton-Presson J, Nair A, Shaw A (2016) Effects of tillage and cover crops on muskmelon production and food safety. Farm Prog Rep 2015:38

Kuan CH, Rukayadi Y, Ahmad SH, Radzi WM, Che WJ, Thung TY, JMKJK P, Chang W-S, Loo Y-Y, Tan C-W, Ramzi OB, SNM F, Kuan C-S, Yeo S-K, Nishibuchi M, Radu S (2017) Comparison of the microbiological quality and safety between conventional and organic vegetables sold in Malaysia. Front Microbiol 8: 1433

Kumar D, Thakur S (2018) Molecular tools to study preharvest food safety challenges. Microbiol Spectr 6:1

Larsen AG, Vogensen FK, Josephsen J (1993) Antimicrobial activity of lactic acid bacteria isolated from sour doughs: purification and characterization of bavaricin A, a bacteriocin produced by Lactobacillus bavaricus MI401. J Appl Bacteriol 75:113-122

Li F, Song Q, Jjemba P, Shi Y (2004) Dynamics of soil microbial biomass $\mathrm{C}$ and soil fertility in cropland mulched with plastic film in a semiarid agro-ecosystem. Soil Biol Biochem 36:1893-1902

Lianou A, Sofos JN (2007) A review of the incidence and transmission of Listeria monocytogenes in ready-to-eat products in retail and food service environments. J Food Prot 70:2172-2198

Lisa G, Palumba JD, Nguyen KD (2004) Strain specific differences in the attachment of Listeria monocytogenes to alfalfa sprouts. J Food Prot 67:2488-2495

Little CL, Taylor FC, Sagoo SK, Gillepsie IA, Grant K, McLauchlin J (2007) Prevalence and level of Listeria monocytogenes and other Listeria species in retail pre-packaged mixed vegetable salads in the UK. Food Microbiol 24:711-717

Locatelli A, Spor A, Jolivet C, Piveteau P, Hartmann A (2013) Biotic and abiotic soil properties influence survival of Listeria monocytogenes in soil. PLoS ONE 8:e75969

López-Gálvez F, Allende A, Pedrero-Salcedo F, Alarcon JJ, Gil MI (2014) Safety assessment of greenhouse hydroponic tomatoes irrigated with reclaimed and surface water. Int J Food Microbiol 191:97-102

Lynch MF, Tauxe RV, Hedberg CW (2009) The growing burden of foodborne outbreaks due to contaminated fresh produce: risks and opportunities. Epidemiol Infect 137:307-315

Macarisin D, Patel J, Sharma VK (2014) Role of curli and plant cultivation conditions on Escherichia coli $\mathrm{O} 157: \mathrm{H} 7$ internalization into spinach grown on hydroponics and in soil. Int J Food Microbiol 173:48-53

Macarisin D, Wooten A, De Jesus A, Hur M, Bae S, Patel J, Evans P, Brown E, Chen Y (2017) Internalization of Listeria monocytogenes in cantaloupes during dump tank washing and hydrocooling. Int J Food Microbiol 257:165-175

Maffei DF, Batalha EY, Landgraf M, Schaffner DW, Franco BDGM (2016) Microbiology of organic and conventionally grown fresh produce. Braz J Microbiol 47S:99-105 
Martínez-Sánchez A, Allende A, Bennett RN, Ferreres F, Gil MI (2006) Microbial, nutritional and sensory quality of rocket leaves as affected by different sanitizers. Postharvest Biol Technol 42:86-97

Maurice Bilung L, Sin Chai L, Tahar AS, Ted CK, Apun K (2018). Prevalence, genetic heterogeneity, and antibiotic resistance profile of listeria spp. and Listeria monocytogenes at farm level: a highlight of ERIC-and BOX-PCR to reveal genetic diversity. Biomed Res Int Article ID 3067494

McLaughlin HP, Casey PG, Cotter J, Gahan CGM, Hill C (2011) Factors affecting survival of Listeria monocytogenes and Listeria innocua in soil samples. Arch Microbiol 193:775-785

Miceli A, Miceli C (2014) Effect of nitrogen fertilization on the quality of Swiss chard at harvest and during storage as minimally processed produce. J Food Qual 37:125-134

Miceli A, Vetrano F, Romano C (2013) Effect of hot air treatment on minimally processed cauliflower. Acta Hortic 1005:309-314

Miceli A, Moncada A, Vetrano F, D'anna F (2014) Effect of packaging on quality of minimally processed fennel. Carpath J Food Sci Technol 6:58-62

Miceli A, Martorana A, Moschetti G, Settanni L (2015a) Hygienic characteristics of radishes grown in soil contaminated with Stenotrophomonas maltophilia. Chem Biol Technol Agric 2:24

Miceli A, Romano C, Moncada A, D'Anna F, Vetrano F (2015b) Effect of cold storage on the quality of minimally processed cauliflower. Carpath J Food Sci Technol 7:70-74

Miceli A, Gaglio R, Francesca N, Ciminata A, Moschetti G, Settanni L (2019) Evolution of shelf life parameters of ready-to-eat escarole (Cichorium endivia var. latifolium) subjected to different cutting operations. Sci Hortic 247:175-183

Milillo SR, Badamo JM, Boor KJ, Wiedmann M (2008) Growth and persistence of Listeria monocytogenes isolates on the plant model Arabidopsis thaliana. Food Microbiol 25:698-704

Mir SA, Shah MA, Mir MM, Dar BN, Greiner R, Roohinejad S (2018) Microbiological contamination of ready-to-eat vegetable salads in developing countries and potential solutions in the supply chain to control microbial pathogens. Food Control 85:235-244

Monaghan JM (2014) Fresh produce crops. In: Finch HJS, Samuel AM, Lane GPF (eds) Lockhart and Wiseman's crop husbandry including grassland, 9th edn. Woodhead Publishing, Cambridge

Monaghan JM, Hutchison ML (2016) Ineffective hand washing and the contamination of carrots after using a field latrine. Lett Appl Microbiol 62:299-303

Moulson G (2011) E. coli death toll up to at least 47. Associated Press

National Advisory Committee on Microbiological Criteria for Foods (1999) Microbiological safety evaluation and recommendation of sprouted seeds. Int J Food Microbiol 52:123-153

Natvig EE, Ingham SC, Ingham BH, Cooperband LR, Roper TR (2002) Salmonella enterica serovar Typhimurium and Escherichia coli contamination of root and leaf vegetables grown in soils with incorporated bovine manure. Appl Environ Microbiol 68:2737-2744

Nicholson FA, Groves SJ, Chambers BJ (2005) Pathogen survival during livestock manure storage and following land application. Bioresour Technol 96:135-143

Núñez-Montero K, Leclercq A, Moura A, Vales G, Peraza J, PizarroCerdá J, Lecuit M (2018) Listeria costaricensis sp. nov. Int J Syst Evol Microbiol 68:844-850

Olaimat AN, Holley RA (2012) Factors influencing the microbial safety of fresh produce: a review. Food Microbiol 32:1-19

Oliveira M, Usall J, Vinas I, Anguera M, Gatius F, Abadias M (2010) Microbiological quality of fresh lettuce from organic and conventional production. Food Microbiol 27:679-684

Oliveira M, Usall J, Vinas I, Solsona C, Abadias M (2011) Transfer of Listeria innocua from contaminated compost and irrigation water to lettuce leaves. Food Microbiol 28:590-596
Orozco L, Rico-Romero L, Escartín EF (2008a) Microbiological profile of greenhouses in a farm producing hydroponic tomatoes. J Food Prot 71:60-65

Orozco RL, Iturriaga MH, Tamplin ML, Fratamico PM, Call JE, Luchansky JB, Escartín EF (2008b) Animal and environmental impact on the presence and distribution of Salmonella and Escherichia coli in hydroponic tomato greenhouses. J Food Prot 71:676-683

Orsat V, Changrue V, Vijaya Raghavan GS (2006) Microwave drying of fruits and vegetables. Stewart Post-Harvest Rev 6:4-9

Orsi RH, Wiedmann M (2016) Characteristics and distribution of Listeria spp., including Listeria species newly described since 2009. Appl Microbiol Biotechnol 100:5273-5287

Pang H, McEgan R, Mishra A, Micallef SA, Pradhan AK (2017) Identifying and modeling meteorological risk factors associated with pre-harvest contamination of Listeria species in a mixed produce and dairy farm. Food Res Int 102:355-363

Park S, Szonyi B, Gautam R, Nightingale K, Anciso J, Ivanek R (2012) Risk factors for microbial contamination in fruits and vegetables at the preharvest level: a systematic review. J Food Prot 75:2055-2081

Park S, Navratil S, Gregory A, Bauer A, Srinath I, Jun M, Szonyi B, Nightingale K, Anciso J, Ivanek R (2013) Generic Escherichia coli contamination of spinach at the preharvest stage: effects of farm management and environmental factors. Appl Environ Microbiol 79:4347-4358

Ponce A, Agüero MV, Roura SI, Del Valle CE, Moreira MR (2008) Dynamics of indigenous microbial population of butterhead lettuce grown in mulch and on bare soil. J Food Sci 73:M257-M263

Putnik P, Bursać Kovačević D, Herceg K, Roohinejad S, Greiner R, Bekhit AE-DA, Levaj B (2011) Modelling the shelf-life of minimally-processed fresh-cut apples packaged in a modified atmosphere using food quality parameters. Food Control 81: $55-64$

Rajwar A, Srivastava P, Sahgal M (2016) Microbiology of fresh produce: route of contamination, detection methods, and remedy. Crit Rev Food Sci Nutr 56:2383-2390

Ricci A, Allende A, Bolton D, Chemaly M, Davies R, Fernández Escámez PS, Girones R, Herman L et al (2018) Listeria monocytogenes contamination of ready-to-eat foods and the risk for human health in the EU. EFSA J 16:5134

Rocourt J, Cossart P (1997) Listeria monocytogenes. In: Doyle MP, Beuchat LR, Montville TJ (eds) Food microbiologyfundamentals and frontiers. American Society for Microbiology Press, Washington, D.C., pp 337-352

Rodriguez-Romo LA, Yousef AE (2006) Microbial stress adaptation and safety of produce. In: Sapers GM, Gorny JR, Yousef AE (eds) Microbiology of fruits and vegetables. CRC Taylor and Francis Group, Boca Raton, pp 95-114

Saltveit ME (1997) Physical and physiological changes in minimally processed fruits and vegetables. In: Tomas-Barberan FA, Robins RJ (eds) Phytochemistry of fruit and vegetables. Oxford University Press, London, pp 205-220

Sant'Ana AS, Franco B, Schaffner DW (2014) Risk of infection with Salmonella and Listeria monocytogenes due to consumption of ready-to-eat leafy vegetables in Brazil. Food Control 42:1-8

Santamaria J, Toranzos GA (2003) Enteric pathogens and soil: a short review. Int Microbiol 6:5-9

Santarelli GA, Migliorati G, Pomilio F, Marfoglia C, Centorame P, D'Agostino A, D'Aurelio R, Scarpone R, Battistelli N, Di Simone F, Aprea G, Iannetti L (2018) Assessment of pesticide residues and microbial contamination in raw leafy green vegetables marketed in Italy. Food Control 85:350-358

Saroj SD, Shashidhar R, Pandey M, Dhokane V, Hajare S, Sharma A, Bandekar JR (2006) Effectiveness of radiation processing in elimination of Salmonella typhimurium and Listeria monocytogenes from sprouts. J Food Prot 69:1858-1864 
Schlech WF, Lavigne PM, Bortolussi RA, Allen AC, Haldane EV, Wort AJ, Hightower AW, Johnson SE, King SH, Nicholls ES, Broome CV (1983) Epidemic listeriosis - evidence for transmission by food. N Engl J Med 308:203-206

Schuchat A, Swaminathan B, Broome CV (1991) Epidemiology of human listeriosis. Clin Microbiol Rev 4:169-183

Scientific Report of EFSA and ECDC (2015) The European Union Summary Report on Trends and Sources of Zoonoses, Zoonotic Agents and Food-borne Outbreaks in 2015. EFSA Journal 13:3991

Scott CA, Faruqui NI, Raschid-Sally L (2004) Wastewater use in irrigated agriculture: management challenges in developing countries. In: Scott A, Faruqui NI, Raschid-Sally L (eds) Wastewater use in irrigated agriculture: confronting the livelihood and environmental realities. CABI Publishing, Oxfordshire, pp 1-10

Selma MV, Allende A, López-Gálvez F, Elizaquível P, Aznar R, Gil MI (2007) Potential microbial risk factors related to soil amendments and irrigation water of potato crops. J Appl Microbiol 103:25422549

Settanni L, Corsetti A (2007) The use of multiplex PCR to detect and differentiate food- and beverage-associated microorganisms: a review. J Microbiol Methods 69:1-22

Settanni L, Corsetti A (2008) Application of bacteriocins in vegetable food biopreservation. Int J Food Microbiol 121:123-138

Settanni L, Miceli A, Francesca N, Moschetti G (2012) Investigation of the hygienic safety of aromatic plants cultivated in soil contaminated with Listeria monocytogenes. Food Control 26:213-219

Settanni L, Miceli A, Francesca N, Cruciata M, Moschetti G (2013) Microbiological investigation of Raphanus sativus L. grown hydroponically in nutrient solutions contaminated with spoilage and pathogenic bacteria. Int J Food Microbiol 160:344-352

Shaw A, Svoboda A, Jie B, Daraba A, Nonnecke G (2015) Importance of hand hygiene during the harvesting of strawberries. Horttechnology 25:380-384

Shenoy AG, Oliver HF, Deering AJ (2017) Listeria monocytogenes internalizes in romaine lettuce grown in greenhouse conditions. J Food Prot 80:573-581

Shrivastava S (2011) Listeria outbreak - bacteria found in romaine lettuce: FDA. Available at: http://www.ibtimes.com/listeria-outbreakbacteria-found-romaine-lettuce-fda-320544 Accessed 28 May 2018

Siddiqui MW, Chakraborty I, Ayal-Zavala JF, Dhui RS (2011) Advances in minimal processing of fruits and vegetables: a review. J Sci Ind Res 70:823-834

Siriamornpun S, Kaisoon O, Meeso N (2012) Changes in colour, antioxidant activities and carotenoids (lycopene, beta-carotene, lutein) of marigold flower (Tagetes erecta L.) resulting from different drying processes. J Funct Foods 4:757-766

Söderqvist K (2017) Is your lunch salad safe to eat? Occurrence of bacterial pathogens and potential for pathogen growth in pre-packed ready-to-eat mixed-ingredient salads. Infect Ecol Epidemiol 7: 1407216

Soerjomataram I, Oomen D, Lemmens V, Oenema A, Benetou V, Trichopoulou A, Coebergh JW, Barendregt J, de Vries E (2010) Increased consumption of fruit and vegetables and future cancer incidence in selected European countries. Eur J Cancer 46:25632580

Ssemanda JN, Reij MW, van Middendorp G, Bouw E, van der Plaats R, Franz E, Muvunyi CM, Bagabe MC, Zwietering MH, Joosten H (2018) Foodborne pathogens and their risk exposure factors associated with farm vegetables in Rwanda. Food Control 89:86-96

Stephan R, Althaus D, Kiefer S, Lehner A, Hatz C, Schmutz C, Jost M, Gerber N, Baumgartner A, Hächler H, Mäusezahl-Feuz M (2015) Foodborne transmission of Listeria monocytogenes via ready-to-eat salad: a nationwide outbreak in Switzerland, 2013-2014. Food Control 57:14-17

Stuart D, Shennan C, Brown M (2006) Food safety versus environmental protection on the Central California coast: exploring the science behind an apparent conflict. The Center for Agroecology \& Sustainable Food Systems

Tango CN, Wei S, Khan I, Hussain MS, Kounkeu PFN, Park J-H, Kim S-H, Oh DH (2018) Microbiological quality and safety of fresh fruits and vegetables at retail levels in Korea. J Food Sci 83:386-392

Te Giffel MC, Zwietering MH (1999) Validation of predictive models describing the growth of Listeria monocytogenes. Int J Food Microbiol 46:135-149

Todd EC, Michaels BS, Smith D, Greig JD, Bartleson CA (2010) Outbreaks where food workers have been implicated in the spread of foodborne disease. Part 9. Washing and drying of hands to reduce microbial contamination. J Food Prot 73 : 1937-1955

Tomasi N, Pinton R, Dalla Costa L, Cortella G, Terzano R, Mimmo T, Scampicchio M, Cesco S (2015) New 'solutions' for floating cultivation system of ready-to-eat salad: a review. Trends Food Sci Technol 46:267-276

Toze S (2006) Reuse of effluent water-benefits and risks. Agric Water Manag 80:147-159

Tromp SO, Rijgersberg H, Franz E (2010) Quantitative microbial risk assessment for Escherichia coli O157:H7, Salmonella enterica, and Listeria monocytogenes in leafy green vegetables consumed at salad bars, based on modeling supply chain logistics. J Food Prot 73: $1830-1840$

U. S. Food and Drug Administration (1998) Guidance for industry, guide to minimize microbial food safety hazards for fresh fruit and vegetables. Available at: http://www.fda.gov/downloads/ Food/GuidanceComplianceRegulatoryInformation/ GuidanceDocuments/ProduceandPlanProducts/UCM169112. pdf Accessed 28 May 2018

Valero M, Hernandez-Herrero LA, Giner MJ (2007) Survival, isolation and characterization of a psychrotrophic Bacillus cereus strain from a mayonnaise-based ready-to-eat vegetable salad. Food Microbiol 24:671-677

Vazquez-Boland JA, Kuhn M, Berche P, Chakraborty T, DominguezBernal G, Goebel W, Gonzalez-Zorn B, Wehland J, Kreft J (2001) Listeria pathogenesis and molecular virulence determinants. Clin Microbiol Rev 14:584-640

von Tersch MA, Carlton BC (1983) Bacteriocin from Bacillus megaterium ATCC 19213: comparative studies with megacin A-216. J Bacteriol 155:872-877

Waitt JA, Kuhn DD, Welbaum GE, Ponder MA (2014) Postharvest transfer and survival of Salmonella enterica serotype Enteritidis on living lettuce. Lett Appl Microbiol 58:95-101

Warriner K, Huber A, Namvar A, Fan W, Dunfield K (2009) Recent advances in the microbial safety of fresh fruits and vegetables. Adv Food Nutr Res 57:155-208

Watkins J, Sleath KP (1981) Isolation and enumeration of Listeria monocytogenes from sewage, sewage sludge and river water. $\mathrm{J}$ Appl Bacteriol 50:1-9

Weller D, Wiedmann M, Strawn LK (2015) Spatial and temporal factors associated with an increased prevalence of Listeria monocytogenes in spinach fields in New York State. Appl Environ Microbiol 81: 6059-6069

Whipps JM, Hand P, Pink DA, Bending GD (2008) Human pathogens and the phyllosphere. Adv Appl Microbiol 64:183-221

Wos A (2016) Interaction between pre-havest and post-harvest systems and their implications for socio-economic development. Available at: http://archive.unu.edu/unupress/food/8F072e/8F072E02.htm. Accessed 28 May 2018 
Yanagida F, Chen Y, Onda T, Shinohara T (2005) Durancin L28-1A, a new bacteriocin from Enterococcus durans L28-1, isolated from soil. Lett Appl Microbiol 40:430-435

Yanagida F, Chen YS, Shinohara T (2006) Searching for bacteriocinproducing lactic acid bacteria in soil. J Gen Appl Microbiol 52:21-28

Zahedi SR, Zahedi SM (2012) Role of information and communication technologies in modern agriculture. Int J Agric Crop Sci 4:1725-1728
Zheng G, Slavik MF (1999) Isolation, partial purification and characterization of a bacteriocin produced by a newly isolated Bacillus subtilis strain. Lett Appl Microbiol 28:363-367

Zhu Q, Gooneratne R, Hussain MA (2017) Listeria monocytogenes in fresh produce: outbreaks, prevalence and contamination levels. Foods 6:21 